\title{
Levéltári nyitás a lakosság felé JNSZ megyében: miért és hogyan?
}

\section{Archival opening to the public in JNSZ County: why and how?}

\section{CSÖNGE A.}

\author{
Magyar Nemzeti Levéltár Jász-Nagykun-Szolnok Megyei Levéltár, csonge.attila@mnl.gov.hu
}

Absztrakt

A Magyar Nemzeti Levéltár Jász-Nagykun-Szolnok Megyei Levéltára, más levéltárakhoz hasonlóan, az elmúlt három évtizedben fokozatosan nyitott a társadalom felé. A tanulmány azokra a kérdésekre keresi a választ, hogy Szolnokon hogyan és miért következett be ez a nyitás. A legszegényebb megyék egyikében kis létszámkeret mellett müködö közgyüjtemény a gazdasági válság éveiben nem leépitette tevékenységét, hanem új közmüvelödési projektekkel szakmai és társadalmi elismerést vivott ki magának. Az iratok gyüjtése és a tudományos kutatómunka mellett széles társadalmi kapcsolatokat kiépito" intézmény az országban elsö levéltárként valósitott meg iskolások tanórán kívüli foglalkozásait célzó TAMMOP pályázatot. Sok éves munkával országosan is egyedülálló kapcsolatot épített ki a megye családkutatóival, melynek eredményeként 2017-ben már a második országos családtörténeti konferenciát rendezték meg nagy sikerrel. Időszaki kiállitásaival nemcsak a levéltárosok kutatási eredményeit teszi közzé, de mára már a magánszemélyek iratajándékozásait is fellenditette. A levéltár ismertségének és elismertségének növelését nagyban elömozdította, hogy a helyi médiával is szoros kapcsolat épült ki. Bár a megyei levéltárak minisztériumi fenntartás alá kerültek, a levéltárosok továbbra is a helyi lakosság igényeinek kielégitését, a kiépitett kapcsolatok megörzését tekintik elsődleges feladatuknak.

Kulcsszavak: Kultúra, társadalmi értékek és életmód szociológiája

Abstract

The Hungarian National Archives Jász-Nagykun-Szolnok County Archives, like other archives, has progressively opened up to society in the past three decades. The study seeks answers to the questions of how and why this opening has happened in Szolnok. This public collection - which operates in the poorest of the counties with small worker number - did not dismantle its activities in the years of the economic crisis, but gained professional and social recognition with new public education projects. The institution has built a wide range of social relations in addition to the collection of documents and the scientific research work and it was the first archives that applied successfully for a TAMOP project aiming for the education of schoolchildren outside of schools. With many years of work the archives has also established a nationwide unique relationship with the county's family researchers, resulting in the second national conference on family history in 2017 with great success. Its periodical exhibitions reveal not only the research results of archivists but for now it has also boosted the document 
giftings of private individuals. Increasing the visibility and recognition of the archives was also greatly enhanced by the close relationship with the local media. Although county archives have been subject to ministry reservation, archivists continue to look to meet the needs of the local population and preserve the established relationships as their primary task.

Keywords: Culture, Sociology of social values and lifestyle

\section{Bevezetés}

A Kedves Olvasó a fenti címadásból talán már sejti, hogy most következö rövid írásomban néhány, a Magyar Nemzeti Levéltár Jász-Nagykun-Szolnok Megyei Levéltárát érintő, alapvető fontosságú kérdést igyekszem megválaszolni. Mint a levéltár jelenlegi igazgatója először is azt vizsgálom meg, hogy milyen sajátosságokkal rendelkezik levéltárunk, majd arra a kérdésre igyekszem megtalálni a választ, hogy miért nyitottunk a lakosság felé, végül pedig néhány kiragadott példán keresztül felvillantom, hogy hogyan is valósult meg a nyitás a gyakorlatban.

\section{A helyi sajátosságok}

A megyék eltérő gazdasági fejlettségüek, ami 2012-ig meghatározta, hogy az önkormányzatok mekkora és milyen felszereltségü levéltárakat tudtak fenntartani. Mindez jelentős különbségek létrejöttéhez vezetett. Az állami kezelésbe vétel és a megyei levéltárak országos összevonása, a Magyar Nemzeti Levéltár létrehozása az infrastrukturális gondok kezelésében komoly elörelépést hozott, míg a humánerőforrás terén a különbségek konzerválódását figyelhetjük meg.

Jász-Nagykun-Szolnok megye a legszegényebb megyék egyike, így nem meglepő módon levéltárunk jelenleg az ország legkisebb összlétszámkeret mellett működő megyei levéltára. Betöltött státuszaink száma 17 és 18 között ingadozik, most épp 17 fö, amiben a takarítónőtől a gazdaságison át az igazgatóig minden dolgozó beleértendő. Más megyékben nagyjából 24-25 fő az átlag, de van, ahol a 34-35 föt is eléri a betöltött státuszok száma. Ezek a gazdasági válság időszakából megörökölt létszámkülönbségek erősen éreztetik hatásukat a levéltárak müködésében, hiszen a kötelező alapfeladatokat és központi projekteket mindenhol el kell végezni, s csak a fennmaradó szabad kapacitásból lehet helyi célokat megvalósítani. (1. kép) 


\section{Szabad munkaerő kapacitás}

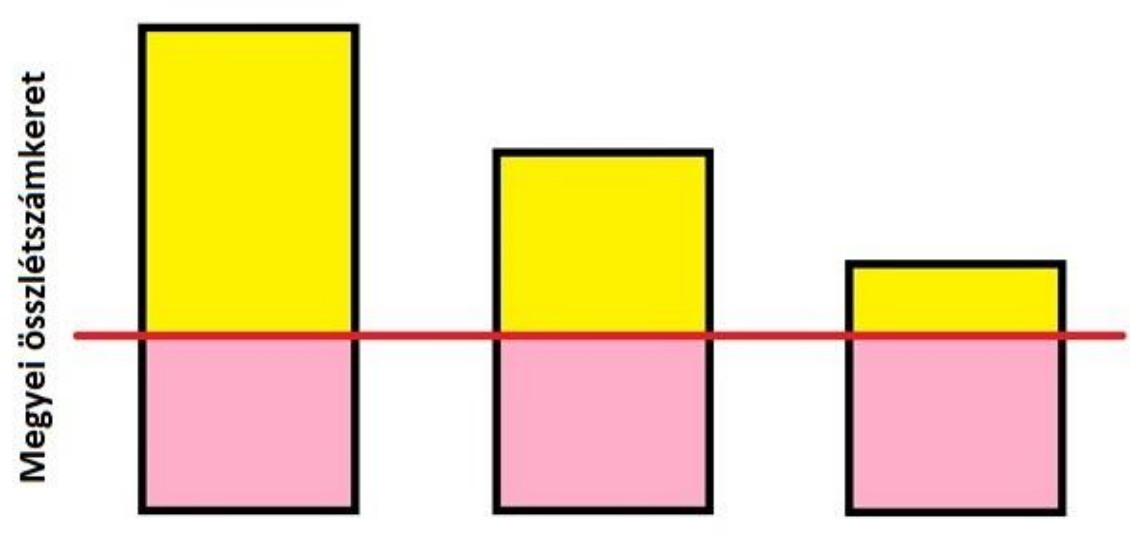

Kötelező alapfeladatok, központi projektek

1. kép: Egyszerüsitett ábra arról, hogy a nagyobb, közepes és kisebb megyei levéltárak eltérő mennyiségü szabad munkaerö kapacitással rendelkeznek, miközben az alapfeladatokat és a Magyar Nemzeti Levéltár által meghatározott központi projekteket megyénként egyenlö arányban kell elvégezniük. ${ }^{l}$

Egy státusz is sokat jelent, de a másfélszeres, kétszeres létszámkülönbség a megyei levéltárak között óriási eltérést eredményez a lehetőségek terén. A Jász-Nagykun-Szolnok Megyei Levéltár jelenleg ennek a spektrumnak a legkedvezőtlenebb végén található.

A levéltárak müködését belülről kevésbé ismerő olvasók kedvéért érdemes röviden összefoglalni a levéltári munka mibenlétét. A könyvtár és múzeum mellett a harmadik közgyüjtemény típus a levéltár, mely a múlt egyedi, írásos emlékeinek őrzője. Szakmai tevékenysége három fő területre osztható. Gyüjtőterületi és ügyfélszolgálati munkára, kutatószolgálati és tudományos munkára, illetve közmüvelődési és közönségkapcsolati munkára. Az elmúlt évtizedek átalakulását türközi, hogy ma már mindhárom munkaterületet kulcsfontosságúnak tartjuk a levéltár fennmaradása és sikeres müködése szempontjából. A maradandó értékü iratok gyüjtése, rendszerezése, őrzése és a jogbiztosító iratokból történő adatszolgáltatás jelenti a levéltári munka alapját. Ezen iratok átvétele, pontos nyilvántartások készítése egyben előfeltétele annak, hogy a levéltárban őrzött iratok kutathatóvá váljanak. Míg a levéltári iratok rendezése, segédletek készítése iránt a társadalom nagy része nem érdeklődik, addig a tudományos kutatási eredmények komoly presztízs kivívására alkalmasak. Bár e kutatómunkát sokan a levéltáros szakmai tevékenység csúcsaként értékelik, ám valódi, széles társadalmi támogatás kivívásához önmagában ez sem elegendő. Mindaz a tudás, amit tanulmányok lapjain és konferenciák előadásaiban prezentálunk, akkor válik valóban közkinccsé, s akkor járul hozzá a tudásalapú társadalom erősítéséhez, ha kilépünk a tudományos élet elefántcsonttornyából és a magas szintű tudományos ismeretekkel nem rendelkező embereket is megszólítjuk. Magától értetődő tehát, hogy a levéltár a gyüjtöterületi és tudományos munka komfortzónáján kívül gazdag közmüvelödési tevékenységi kört is fel kell hogy vállaljon. Mindez csak a mai kor emberének tünhet evidensnek, hiszen például a 80-as évek elején megjelent levéltár ismertetők még csak az egyes levéltárakban örzött irategyütteseket mutatták be részletesen, a megjelent segédleteket és forrásközléseket csak címszavakban ismertették, közmüvelődési tevékenységről pedig egy szót sem ejtettek. $^{2}$

${ }^{1}$ Saját szerkesztés, 2017

${ }^{2}$ Tóth 1983. 198-205. 
Helyi sajátosság Jász-Nagykun-Szolnok megyében, hogy levéltárunk más levéltárakhoz képest tovább volt a lakosságtól elzárkózó, kizárólag a hivatali munkára, iratgyüjtésre és őrzésre fókuszáló intézmény, egészen az 1980-as évek közepéig. Ekkor lett olyan igazgatója az intézménynek, aki már diplomával is rendelkezett, sőt, tudományos fokozattal. Dr. Botka János személyével az intézmény müködésében is komoly szemléletváltás következett be, elkezdödött egy lassú, de fokozatos nyitás a lakosság felé. A gyüjtöterületi alapfeladatok mellett így előbb a tudományos életbe kapcsolódtak be a levéltár munkatársai. Megjelent évkönyvünk, a Zounuk, mely azóta is a megye legrégebbi, folyamatosan megjelenő, tudományos periodikája.

Majd egy újabb igazgatóváltással, Dr. Zádorné dr. Zsoldos Mária hivatalba lépésével, a 90-es évektől útjára indult éves konferenciánk, a Levéltári Nap. E tudományos tanácskozás a levéltár legrangosabb rendezvénye lett, melynek hagyományosan a Megyeháza díszterme ad otthont. Ezzel párhuzamosan a szélesebb társadalmi kapcsolatok kiépülése érdekében időszaki kiállítások megrendezését is felvállalta közgyüjteményünk.

A következő igazgatóváltás a közönségkapcsolatok további bővülését hozta. Dr. Fülöp Tamás vezetése mellett, 2008-tól fokozottabb tempóban vállaltuk fel a közmüvelödési feladatokat, gyermekcsoportok fogadásával és gyakori, helyi médiaszereplésekkel. Nagyjából ezen időszaktól kezdődően az ország levéltárai, köztük a Jász-Nagykun-Szolnok megyei is, a változó szakmai, fenntartói és társadalmi igényekhez igazodva, müködésüket a „szolgáltató levéltár” koncepció jegyében határozták meg, sokszínü programok indultak és fellendült az online tartalomszolgáltatás. (2. kép)

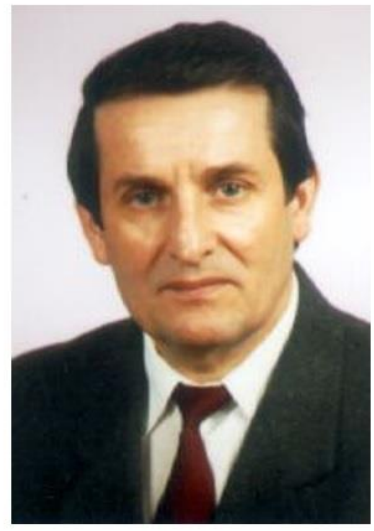

Dr. Botka János (1986-1993)

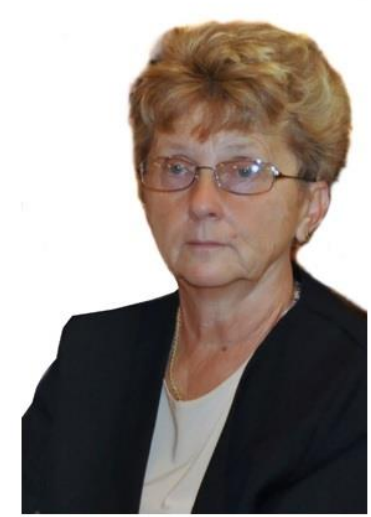

Dr. Zádorné dr. Zsoldos Mária (1993-2007)

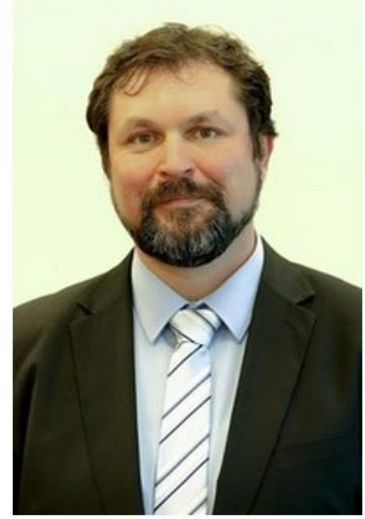

Dr. Fülöp Tamás (2008-2013)

2. kép: A megyei levéltár igazgatói és hivatali idejük

\section{Miért nyitottunk a lakosság felé?}

A tudományos élet felé való nyitás azért volt különösen fontos levéltárunk esetében, mert megyénkben egyetemi szintű történészképzés nincs, sőt a meglévő szolnoki gazdálkodási szakos képzés is végnapjait éli. A miénkhez hasonló megyékben a helyi levéltárak és múzeumok tudományos életben betöltött szerepe ezáltal felértékelődik, tudományos mühelyként egyedül ezen intézmények funkcionálnak, csak a közgyüjtemények falai között dolgoznak és kutatnak hivatásszerüen történészek. Helyben nincs egyetem és nincsenek tudományos kutatóintézetek (mint pl. a Nemzeti Emlékezet Bizottsága, az 56-is Intézet, a Terror Háza stb.), Budapestről pedig tapasztalataink szerint nem utaznak le Szolnokra történészek, még abban az esetben sem, ha valamely megyei témáról írnak, miközben a 
Szolnok és Budapest közötti 100 km-es távolság leküzdése nem volna lehetetlen vállalkozás. A megyében müködő városi múzeumok elsősorban székhelyük és vonzáskörzete tárgyi emlékeit gyüjtik, saját kistérségük történetét kutatják. A muzeológusok döntő többsége a régészeti leleteket vizsgálva a 18. század és az azt megelőző korok kutatója. A levéltár kutatótermébe járó amatőr kutatók pedig rendszerint saját családfájukat kutatják. Komolyan vehető helytörténész, aki tudományosan értékelhető munkát is letesz az asztalra, alig féltucatnyi akad az egész megyében. Ha tehát mi magunk nem kutatjuk a levéltárban őrzött, döntően 19-20. századi iratokat, akkor más sem tárja fel helyettünk a megye legújabb kori történetét, így a levéltárosok tudományos szerepvállalása nélkülözhetetlen és pótolhatatlan. Bármely történelmi évforduló (1848, 1914-1918, 1945, 1956 stb.) kapcsán egyaránt él az igény a helyi lakosság, a helyi médiumok és a helyi politikusok részéről, hogy a nagy nemzeti sorsfordulók helyi vonatkozásait is megismerhessék, történelemkönyvekből származó átfogó ismereteiket helytörténeti adalékokkal tegyék emberközelivé, személyesen átélhetővé. A helyi identitás erősítése, hiteles és pontos történelmi tények feltárása és bemutatása a megyei levéltárosok szerepvállalása nélkül nem lehetséges. A levéltári kutatási eredmények közzétételéhez megfelelő és elengedhetetlen fórumot pedig évkönyvünk, tematikus kiadványaink és konferenciánk biztosít, melyek helyi és országos szinten is magas színvonalat és szakmaiságot képviselnek.

Annak érdekében viszont, hogy ne csak a müvelt elit körében növeljük a levéltár elismertségét, szükséges az is, hogy a tudományos kutatási eredményeket különböző korosztályok és eltérő müveltségü társadalmi csoportok nyelvére is lefordítsuk. Mindaz a tudás, amit tanulmányok lapjain és konferenciák előadásaiban prezentálunk, akkor válik valóban közkinccsé, ha kilépünk a tudományos élet elefántcsonttornyából és a tudományos ismeretekkel nem rendelkező embereket is megszólítjuk. Ezt célozzák közmüvelödési programjaink, melyek egyre inkább a korábbi évtizedekben megszokottól eltérő készségeket és szemléletmódot követeltek meg a levéltárak munkatársaitól.

A 2000-es évek végére azért lett épp a Jász-Nagykun-Szolnok Megyei Levéltár az egyik ,élharcosa” e szemléletváltásnak, mert a gazdasági válság éveiben új igazgatónk arra a felismerésre jutott, hogy az újabb és újabb megszorítások elől hátrálva nem leépíteni kell tevékenységünket, hanem elöre menekülni, aminek kulcsa a közmüvelődési munka. Alapvetően tehát a létért vívott harc volt a fö motivációs tényező, annak végiggondolása, hogy hogyan lehet anyagi források nélkül, a meglévő tudásra építve növelni ismertségünket és elismertségünket, bízva abban, hogy egy sikeres intézmény mellé a döntéshozók is szívesebben odaállnak és áldoznak ránk költségvetési forrásokat. Ezen várakozásunk szerencsésen beigazolódott, a gazdasági válság éveiben a megszorítási hullámnak az ismertségünk és elismertségünk növelésével, a levéltárosok szaktudásának jobb társadalmi hasznosulását előmozdító változatos tevékenységünkkel sikerült helyben gátat szabni.

A most előttünk álló időszakban pedig az egész szakma számára további motivációs tényező lehet a tudományos és az arra épülő közmüvelödési tevékenység fokozására, hogy a közigazgatásban az elektronikus iratok mindinkább teret hódítanak. A papíralapú iratok vélhetően sohasem tünnek el, de arányuk kétségtelenül vissza fog szorulni. Éppen ezért nem célszerü a levéltárak tevékenységét kizárólag a papíralapú iratok átvétele és rendezése köré építeni, hacsak nem akarjuk önmagunkat lassú sorvadásra ítélni. A tudományos kutatómunka és az ezek eredményeit prezentáló közművelődési feladatok ellenben hosszú távon, új papíralapú iratok átvétele nélkül, a már átvett iratokra alapozva is stabilan fenntarthatóak és igazolhatják a levéltárak létét.

\section{Hogyan nyitottunk a lakosság felé?}

Idén jelent meg évkönyvünk 31. kötete, és 20. alkalommal rendeztük meg éves Levéltári Nap konferenciánkat. ${ }^{3}$ Ez önmagában még nem különleges dolog, ilyesmire más megyékben is találunk példát. Ugyanakkor több évtizedes fenntartásuk a gazdasági nehézségek és költségvetési megszorítások időszakában komoly feladat volt.

Helyi sajátosság viszont, hogy Budapesten kívül elsőként Jász-Nagykun-Szolnok megyében létesültek családfakutatók klubok, mégpedig Mezőtúron és Szolnokon. Egyéni kutatók mindenhol vannak, de

32003-ban Szolnokon tartották a Magyar Levéltárosok Egyesülete éves vándorgyülését, melynek szervezésében és lebonyolításában a megyei levéltár is oroszlánszerepet vállalt, így abban az évben Levéltári Napot nem rendeztünk. 
Régiókutatás Szemle 2018/1 sz. DOI: $10.30716 / \mathrm{RSZ} / 2018 / 1 / 3$

klubélet sokáig csak a mi megyénkben volt. Előbb szervezetten fogadtuk tagjaikat, majd a szolnoki klubnak otthont adó Aba-Novák Agóra Kulturális Központban segítettük klubrendezvényeiket előadások megtartásával, mely előadásokból az ANKK jóvoltából rendkívül sikeres módszertani segítséget nyújtó füzetek álltak össze „Kis füzetben nagy segítség” címmel, mely sorozatnak idén jelent meg a harmadik füzete. ${ }^{4}$ Emellett közös, országos családfakutató konferenciákat is szerveztünk 2015-ben és 2017-ben is, neves előadókkal, nagy sikerrel.

Konferenciáink sikerét mutatja, hogy Levéltári Napunk mintegy száz fös közönsége rendszeresen megtölti a Megyeháza dísztermét, legutóbbi családfakutató konferenciánk pedig 140 főnyi érdeklődött vonzott változatos előadásaival, programjaival. Ezzel rendezvényeink messze túlmutatnak a néhány érdeklődő mellett egymásnak prezentációkat tartó előadók tudományos konferenciáinak népszerüségén.

Rendszeresen készítünk időszaki kiállitásokat is. Ezek közül kiemelném az 56-os évforduló alkalmából a város felkérésére létrehozott köztéri kiállításunkat, melyet a város négy forgalmas terén mutattunk be óriás táblákra nyomtatva, így több ezren láthatták azokat. ${ }^{5} \mathrm{~A}$ megvalósítást a város pályázati forrásból finanszírozta, ugyanakkor az együttmüködés mutatja, hogy hiába van a városnak múzeuma és egyéb kulturális intézményei, a 20. század történelmének feltárásához, a helyi események bemutatásához elengedhetetlen a levéltárosok munkája és ezt elvárják akkor is, ha nem ők a fenntartóink. (3. kép)

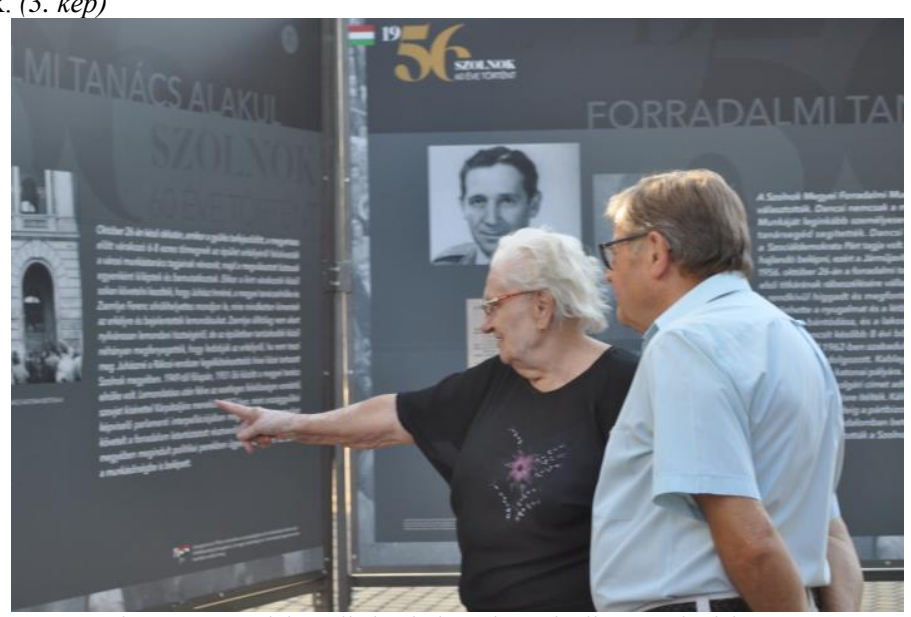

3. kép: 56-os emlékév alkalmából rendezett kiállitás Szolnok közterein

Külön említést érdemel a 2016 őszén indult és azóta is futó „Bővülö történelem - Az elmúlt tizenöt év iratajándékozásai" címü program-folyam is, mely 6 megyei levéltár, valamint az Országos Levéltár részvételével valósul meg. Ezen összefogás eredményeként egyrészt sikerült Budapesten is bemutatni a levéltárunkban folyó munkát, illetve azt, hogy a sajtó és a média segítségével milyen értékes dokumentumokkal, fotókkal, hagyatékokkal gyarapíthattuk állományunkat. Másrészt az országos vándorkiállítás időszaki bemutatásán túl, egyéni kezdeményezésként - a CO:OP projekt támogatásával - létrehoztuk e tárlat saját, megyei vándorkiállítás-verzióját is, poszterekre nyomtatva. Megyei hatókörü intézményként ugyanis nem csak a szolnoki, hanem a vidéki lakosságot is szeretnénk megszólítani, s e nyomtatott kiállítást immáron bármely településen bemutathatjuk, ezáltal jobban megismertethetjük levéltárunkat a megye lakosságával. Ez a programunk Jászberényben debütált, az irat- és tárgyadományokat bemutató „Múltunk öröksége - Bővülő történelem” című, Jász Múzeummal

\section{${ }^{4}$ Ari 2017.}

${ }^{5}$ http://mnl.gov.hu/mnl/jnszml/hirek/56_os_kiallitasmegnyito_szolnokon Letöltés ideje: 2017. december 31. 
Régiókutatás Szemle 2018/1 sz. DOI: $10.30716 / \mathrm{RSZ} / 2018 / 1 / 3$

közös kiállításunkon, majd 2017 öszén a szolnoki Aba-Novák Agóra Kulturális Központ két országos rendezvényén (családkutató konferencia és csokifesztivál) is bemutatásra került. ${ }^{6}$

Az iratajándékozást népszerüsítő kampányunknak köszönhető 2017 egyik legjelentősebb irathagyatékfelajánlása is: a Magony László által életre hívott, nemzetközi hírü, szolnoki székhelyü MONFODI (Mozgáskorlátozottak Nemzetközi Fotó- és Színesdia Pályázat) Közhasznú Alapítvány dokumentumai, valamint több ezres nagyságrendủ pályázati fotói kerültek a levéltár örizetébe. Az átvett színes fényképekből azóta Törökszentmiklóson, valamint a Verseghy Ferenc Könyvtárban is nyílt tárlat. Utóbbi az „Én is vagyok! Mozgássérült Generációk Érdekvédelmi Egyesülete” - melynek Magony László maga is tagja volt - kétnapos rendezvénysorozatának egyik állomása volt. ${ }^{7}$

Az esélyegyenlőség biztosítása hangsúlyosan szerepel levéltárunk küldetésnyilatkozatában, így korábban együttmüködtünk a vakokat tömörítő Fehér Bot Alapítvánnyal is, míg 2017-ben a Siketek és Nagyothallók Országos Szövetségének tagjait fogadtuk a levéltárban. ${ }^{8}$ Bár rendezvényeink többségével a tömegek megszólítása a cél, emellett fontosnak érezzük, hogy ezen kisebb létszámú csoportok is megismerhessék a levéltárat és állampolgárokként igénybe tudják venni szolgáltatásainkat. Sajnos ma még kevés közintézmény fordít erre figyelmet.

Nagyobb csoportot jelent az iskolások tömege, akiket más közgyüjteményekhez hasonlóan mi is igyekeztünk bevonni közművelödési tevékenységünkbe, mivel az iskolák révén szervezetten megszólíthatók. A mi levéltárunk volt az első, amely sikeresen pályázott uniós TÁMOP projektre, iskolán kívüli oktatási tevékenység segítésére. Ennek keretében 6 év alatt összesen 2161 hátrányos és halmozottan hátrányos helyzetű diák vett részt levéltár-pedagógiai foglalkozásainkon. ${ }^{9}$ (4. kép) A program hat éve gyakorlatilag egybe esett a gazdasági válság utáni időszakkal. A költségvetési megszorításokra adott, országos visszhangot kiváltó kezdeményezéseink közül talán ez járt a legnagyobb szakmai elismeréssel és jelentősen növelte a média és a lakosság érdeklődését is intézményünk felé.

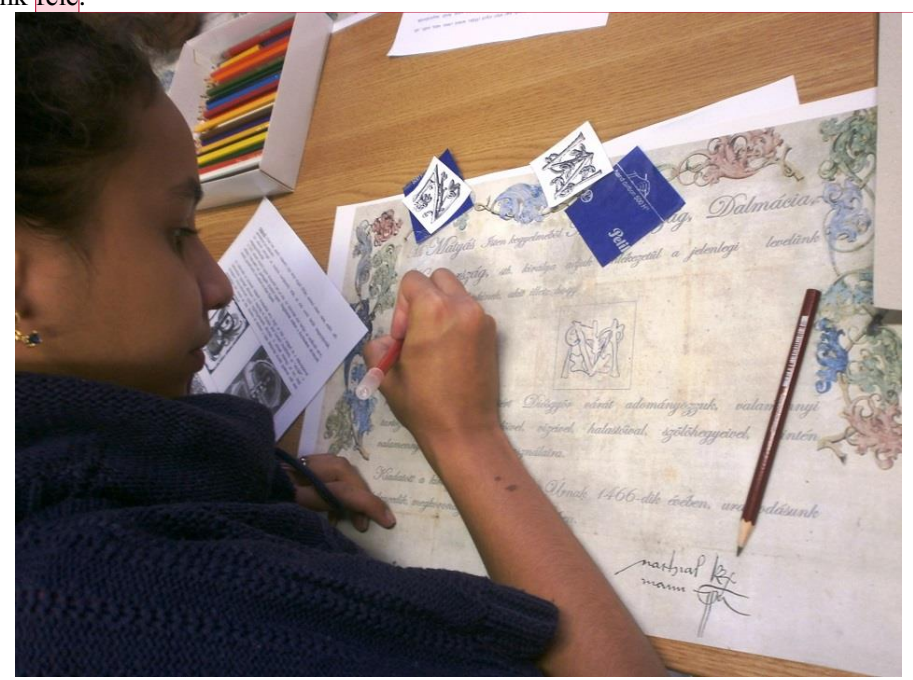

[W1] megjegyzést írt: javasolt: iránt

${ }^{6} \underline{\mathrm{http}} / / / \mathrm{mnl} . g o v . h u / \mathrm{mnl} / \mathrm{jnszml} / \mathrm{hirek} /$ kozos_muzeumi_leveltari_kiallitas_jaszberenyben Letöltés ideje: 2017. december 31 .

${ }^{7}$ http://mnl.gov.hu/mnl/jnszml/hirek/monfodi_alkotasokbol_nyilt_kiallitas_a_verseghy_ferenc_megyei_konyvtar ban Letöltés ideje: 2017 . december 31.

${ }^{8} \mathrm{http}: / / \mathrm{mnl} . g o v . h u / \mathrm{mnl} / \mathrm{jnszml} /$ hirek/ismeretszerzes_erzekszervi_korlatok_nelkul Letöltés ideje: 2017. december 31.

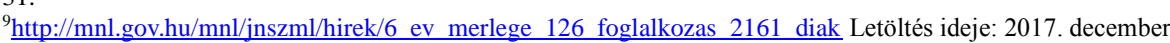
31. 
A TÁMOP foglalkozások mellett és azokon túl is rendszeresen tartunk rendhagyó történelemórákat. Különösen népszerủek papir- és irástörténeti foglalkozásaink, melyek az egykori Szolnoki Papírgyártól átvett állandó kiállításra épülnek és az óvodásoktól kezdve a nyugdíjasokig minden korosztály számára élményszerủen mutatják be az íráshordozók fejlődését és a papírmerítés titkát. ${ }^{10}{ }^{(5}$. kép)

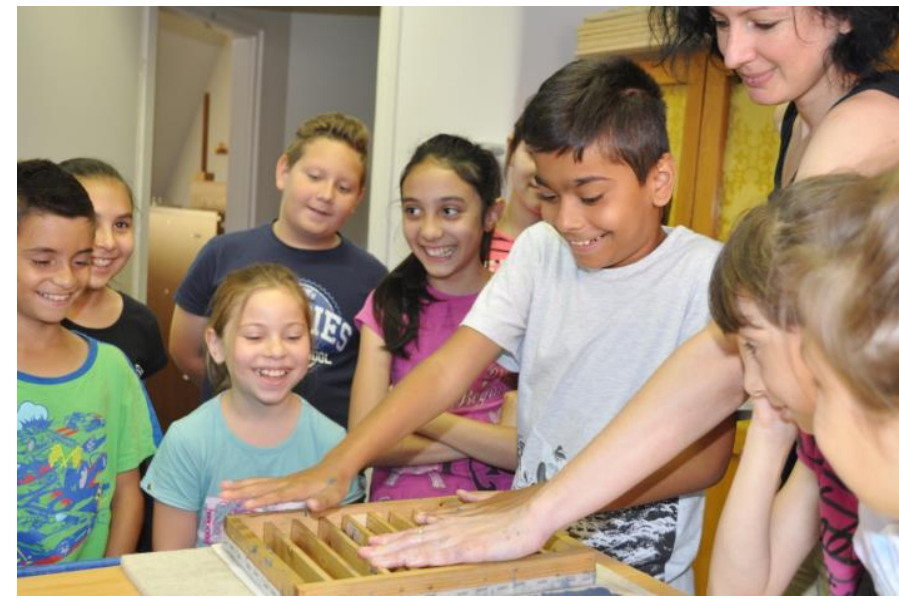

5. kép: Papirmerités a Jász-Nagykun-Szolnok Megyei Levéltárban

Újabb példa a helyi közösségek szolgálatára, hogy egyik levéltáros kollégánk összeállította a megye első világháborús hösi halottainak adatbázisát a halotti anyakönyvekből. Ez a veszteséglista azért fontos, mivel az emlékmüveken nem minden esetben vannak névsorok, vagy ha vannak, akkor azok hiányosak, hiszen voltak olyan esetek, amikor csak évtizedekkel később nyilvánítottak holttá valakit. E kutatásnak köszönhetően a rákóczifalvi, szajoli, tószegi valamint a tiszaföldvári világháborús emlékművek centenáriumi évfordulóhoz kapcsolódó felújításakor az azokon szereplő névsorokat kiegészítették az újonnan kikutatott nevekkel. Másrészt ezen kutatómunka jelentőségét felismerve a Magyar Nemzeti Levéltár országos projektté terjesztette ki a halotti anyakönyvekből az első világháború áldozatainak kutatását.

Eltérés más megyékhez képest, hogy nálunk a helyi média különösen sokszor közöl híreket levéltárunkról. 2017-ben összesen 108 alkalommal szerepeltünk az elektronikus sajtóban, 77-szer a nyomtatott sajtóban, 24-szer a televízióban és 11-szer a helyi rádiókban, ami azt gondolom, hogy országosan is kimagaslóan jó arány és sok éves kapcsolatépítési munka eredménye. Egyik kollégánk maga is folyamatosan publikál hosszabb ismeretterjesztő cikkeket a megyei napilapban, amelyek kéthárom hetente meg is jelennek. Ezen kívül 2016-ban új televíziós magazinmüsort indítottunk „Levéltári kincseink” címmel, melyben egy-egy levéltáros kollégánk mesél a számára kedves iratokról, térképekről. A felvett, öt-tízperces részeket rendszeresen ismétli a televízió, így mind többen nyerhetnek bepillantást a levéltárak színfalai mögé, és megismerhetik magukat a levéltárosokat is. ${ }^{11}$

A sajtómegjelenések mellett gondot fordítunk saját, intézményi honlapunk és Facebook oldalunk rendszeres frissítésére is. Időszaki kiállításainkból virtuális kiállításokat készítünk, tudósítunk rendezvényeinkről. Színes tartalmukból példaként említhető, hogy 2009 óta folyamatosan közzéteszünk egy-egy érdekes iratot „Hónap dokumentuma” rovatunkban, de a Szolnok Televízió müsoraiban történő részvételeink is könnyedén megtekinthetőek weboldalunkon, köszönhetően az adások internetre történő feltöltésének és átlinkelhetőségének.

${ }^{10} \mathrm{http}: / / \mathrm{mnl} . g o v . h u / \mathrm{mnl} / \mathrm{jnszml} / \mathrm{hirek} /$ papirfelesegek_ovis_szemmel_avagy_nagyito_alatt_a_korai_irashordozok Letöltés ideje: 2017. december 31.

${ }^{11} \mathrm{http} / / / \mathrm{www}$. szolnoktv.hu/musorok/leveltari_kincseink Letöltés ideje: 2017. december 31. 


\section{4. Összegzés}

A Jász-Nagykun-Szolnok Megyei Levéltár kis munkatársi létszáma ellenére mára ismert és elismert intézménnyé vált, széles társadalmi kapcsolatokkal, kiemelkedő helyi médiaérdeklődéssel övezve. Ugyanakkor a 2012-ben bekövetkezett fenntartóváltás, az önkormányzatiból állami fenntartás alá kerülés és országos összevonás két fontos következménnyel is járt.

Egyrészt azzal, hogy helyi ismertségünk az országos, minisztériumi, fenntartói döntéseket már nem befolyásolja. Immáron messze a fejünk fölött születnek meg a létünket meghatározó döntések, amelyeket leginkább a központi költségvetési megtakarítás motivál. A kultúra ugyanakkor jellemzően nem tartozik állami szinten a túlfinanszírozott ágazatok közé. A közgyüjtemények még szerényebb szerepet játszanak az állami kultúrpolitikában, ezen belül pedig a múzeumok és könyvtárak mellett a levéltárak hangja a legkisebb, illetve maga a levéltáros szakma is megosztott, képtelen az egységes fellépésre, érdekérvényesítésre.

Másrészt a megyei levéltárak országos összevonásának eredményeként megjelentek olyan központi projektek (jellemzően iratfeltárás, digitalizálás és adatbázis építés), melyek épp a behatárolt költségvetési források kiegészítését célozzák, plusz bevételt eredményeznek a Magyar Nemzeti Levéltár egésze számára, ezért az országos központ szemében is elsődleges fontosságúak. Az e projektekkel járó feladatok a törvényileg meghatározott alapfeladatokra rakódva értelemszerúen tovább csökkentik a helyi társadalmi igények kielégítésére fordítható helyi munkaerő kapacitást.

A megyei levéltárak dolgozói ugyanakkor továbbra is a helyi közösségek részei, s elsősorban arra törekednek, hogy a megye lakosságának igényeit szolgálják ki. Hiszen nem egy aktatologató, köldöknézegető intézmény képét akarjuk mutatni a lakosság felé, hanem szeretnénk megőrizni az évtizedek alatt, megfeszített munkával elért társadalmi beágyazottságunkat, tovább növelni ismertségünket, elismertségünket. Egyszerre kell tehát megfelelnünk a fenntartói és a Magyar Nemzeti Levéltár központi elvárásainak és a helyi társadalmi igényeknek, melyek összeegyeztetése, gyakorlati megvalósítása komoly kihívások elé állítja a kis létszámú levéltárakat.

Az intézményi és társadalmi változásokkal együtt járó akadályokat eleddig sikeresen vette levéltárunk, amit bizonyít, hogy a fentebb részletezett munkánkat méltányolva a Magyar Levéltárosok Egyesülete az „Év Levéltára 2017” Díjat a Magyar Nemzeti Levéltár Jász-Nagykun-Szolnok Megyei Levéltárának ítélte. E magas rangú szakmai kitüntetés elnyerése természetesen nem csupán egy évnyi teljesítmény, hanem több éven át, országosan is kiemelkedő színvonalon végzett munkánk elismerését jelenti. Éppen ezért a jelenlegi csapat tagjai mellett köszönet illeti azon egykori munkatársainkat is, akik a 80-as évektől kezdve levéltárunkban dolgoztak és hozzájárultak a társadalmi nyitás sikeréhez. De köszönettel tartozunk azon társintézményeknek is, akik partnerségük révén hosszú idő óta támogatták rendezvényeinket és azt, hogy közművelődési munkánk a megyei média érdeklődésének fókuszába kerülhetett.

\section{Irodalomjegyzék}

Kis füzetben nagy segitség a családkutatáshoz 3. Szerk. biz.: Ari Ilona-B. Sipos GabriellaKollega Tarsoly István. Szolnok, 2017.

Czégény Istvánné-Cseh Géza-Csönge Attila-Mákos Judit-Szabóné Maslowski Madlen-Szikszai Mihály: A Magyar Nemzeti Levéltár Jász-Nagykun-Szolnok Megyei Levéltára. Székesfehérvár, 2015.

Zounuk 31. A Magyar Nemzeti Levéltár Jász-Nagykun-Szolnok Megyei Levéltára évkönyve. Szerk. biz.: Csönge Attila-Pozsgai Erika-Szabóné Maslowski Madlen. Szolnok, 2017.

Káli Csaba: A Magyar Nemzeti Levéltár Megyei Levéltárai. Magyarország Levéltárai 2014. Szerk.: Hermann István. Budapest, 2015. 32-46.

Tóth Tibor: Szolnok megyei Levéltár. Magyarország Levéltárai. Szerk.: Balázs Péter. Budapest, 1983. 198-205. 